
ISSN : 2615-1995, E-ISSN : 2615-0654

J. Madani., Vol. 3, No. 1, Maret 2020 (141 - 150)

(C)2018 Lembaga Kajian Demokrasi

\title{
Pengaruh Etos Kerja dan Disiplin Kerja Terhadap Kinerja Karyawan Pada PT Pacific Indah Pratama Jakarta
}

\author{
Akhmar Barsah \\ Fakultas Ekonomi, Universitas Pamulang \\ dosen01578@unpam.ac.id \\ Asep Ridwan \\ Fakultas Ekonomi, Universitas Pamulang \\ asepr9672@gmail.com
}

\begin{abstract}
Abstrak
Penelitian ini bertujuan untuk mengetahui serta membuktikan kesesuaian antara teori dengan fakta terkait seberapa besar variabel-variabel prediktor etos kerja dan disiplin kerja berpengaruh terhadap variabel yang dipengaruhi kinerja karyawan. Pendekatan metode kuantitatif dengan bentuk asosiatif (kausal) penulis gunakan dalam penelitian ini. Sampel berdasarkan populasi yang ada berjumlah 103 responden, di mana seluruh populasi dijadikan sampel dengan teknik nonprobability sampling yaitu sampel jenuh. Teknik analisis data menggunakan statistik inferensial (parametris) dengan uji kelayakan data meliputi uji validitas dan uji reliabilitas, uji prasyarat atau asumsi dasar regresi yaitu normalitas residual, multikolinieritas, heteroskedastisitas. Sedangkan uji hipotesis dilakukan uji $F$, uji uji $t$, analisis korelasi, analisis koefisien determinasi, dan persamaan regresi berganda. Hasil temuan penelitian berdasarkan rangkaian uji dapat disimpulkan. Hasil uji F (simultan) variabel prediktor (etos kerja dan disiplin kerja), berpengaruh positif dan signifikan terhadap variabel dependen (kinerja karyawan) di mana nilai $F_{\text {hitung }}>F_{\text {tabel }}(34.855>3.09)$ ). Hasil uji signifikansi etos kerja terhadap kinerja karyawan mempunyai pengaruh positif dan signifikan, di mana nilai $t_{\text {hitung }}>t_{\text {tabel }}(5.212>1.98)$. Demikian pula disiplin kerja terhadap kinerja karyawan berpengaruh positif dan signifikan, di mana nilai $t_{\text {hitung }}>t_{\text {tabel }}(4.997>1.98)$. Besaran korelasi variabel prediktor yaitu etos kerja dan disiplin kerja terhadap kinerja karyawan didapat angka 0.641 yang mengartikan adanya korelasi yang kuat (0.600-0.799). Persentase koefisien determinasi variabel prediktor (etos kerja dan disiplin kerja) terhadap variabel dependen (kinerja karyawan) sebesar 39.9\% di mana $60.1 \%$ adalah faktor-faktor lain yang tidak teridentifikasi. Sedangkan persamaan regresi didapat $Y=0.799+0.428+0.432$.
\end{abstract}

Kata Kunci : Etos Kerja, Disiplin Kerja, Kinerja Karyawan

\begin{abstract}
This study aims to determine and prove the appropriateness of theory with facts, the influence of work ethic and work discipline on employee performance. The quantitative method approach with an associative (causal) form is used in this study. The sample based on the existing population is 103 respondents. The entire population is sampled with a non-probabilistic sampling technique that is a saturated sample. Data analysis techniques that use inferential statistics (parametric) with the data eligibility test include validity and reliability tests, tests of prerequisites or regression assumptions that are residual normality, multicollinearity, and heteroscedasticity. The hypothesis test is performed using the F test, the t test, the correlation analysis, the analysis of the coefficient of determination and the multiple regression equations. The results based on the series of tests can be concluded. The predictive variables of $F$ (simultaneous) test results (work ethic and work discipline) have a positive and
\end{abstract}


significant effect on the dependent variable (employee performance) the value of $F_{\text {count }}>F_{\text {table }}(34,855>3.09)$. The results of the test of the importance of work ethic in the performance of employees have a positive and significant effect, the value of $t_{\text {count }}>t_{\text {table }}(5,212>1.98)$. Similarly, labor discipline in the performance of employees has a positive and significant effect, the value of $t_{\text {count }}>t_{\text {table }}(4,997>1,998)$. The magnitude of the correlation predictor variables, namely work ethic and work discipline on employee performance, obtained a number of 0.641, which means a strong correlation (0.600-0.799). The percentage coefficient of determination of the predictive variables (work ethic and work discipline) to the dependent variable (employee performance) is $39.9 \%$, where $60.1 \%$ are other factors that are not identified. While the regression equation obtained $Y=0.799+0.428+0.432$.

Keywords : Work Ethic, Work Discipline, Employee Performance

\section{PENDAHULUAN}

Tekanan di dalam bisnis dewasa ini sangat dirasakan oleh perusahaan-perusahaan yang berusaha untuk tetap hidup dan tumbuh sehat serta berkembang guna menghadapi persaingan yang semakin terbuka. Untuk mewujudkannya tentu perusahaan harus mengkaji secara komprehensif, tidak hanya modal berbentuk uang yang menjadi unsur penting dalam kegiatan bisnis perusahaan. Tetapi faktor-faktor lain juga tidak bisa diabaikan atau dipisahkan karena mempunyai keterikatan dalam operasionalnya.

Perusahaan dituntut mampu beradaptasi dengan perubahan yang cepat terjadi baik dari sisi teknologi, sosial, regulasi, budaya dimasyarakat dan juga kondisi ekonomi serta politik yang selalu berjalan beriringan. Dewasa ini kualitas sumber daya manusia saat ini menjadi fokus utama pada suatu perusahaan, untuk menghadapi persaingan bisnis yang semakin tinggi. Sudah barang tentu perusahaan akan mencari sumber daya manusia dengan kriteria yang mempunyai kompetensi handal sehingga dapat berkontribusi bagi perusahaan. Untuk itu perusahaan harus mampu menyusun suatu perencanaan baik dari sisi bisnis maupun sumber daya manusianya.

Tercapainya suatu tujuan perusahaan dari apa yang telah ditetapkan tentu berdasarkan kontribusi hasil sumber daya manusianya terhadap perusahaan, karena keberhasilan perusahaan berkaitan dengan pencapaian dari kinerja karyawannya. Perubahan yang sering terjadi dalam lingkungan bisnis mendorong perusahaan untuk adaptif terhadap tuntutan keadaan yang ada dan untuk mencapai kesuksesan perusahaan harus dapat menumbuhkan etos kerja karyawan. Sudah tentu tidak begitu saja etos kerja terbentuk pada individu karyawan dibutuhkan juga kesadaran akan kepatuhan terhadap aturan-aturan yang akan membentuk kedisiplinan karyawan meningkat.

Tempat penelitian dilakukan pada PT Pacific Indah Pratama yang bergerak dibidang produsen dan produksi perakitan sepeda yang beralamat di Komplek Ruko Toho Blok H 18-26, Jl. Pantai Indah Barat Rt/Rw 03 Kamal Muara, Penjaringan, Jakarta Utara. Produksi perakitan antara lain seperti sepeda lipat, sepeda anak-anak, BMX, CTB dan MTB. Produktivitas perusahaan secara umum sangat dipengaruhi oleh kinerja karyawan yang baik sehingga dapat bertahan dalam menghadapi persaingan global dewasa ini. Kemunduran kualitas kerja karyawan PT Pacific Indah Pratama masih terbilang tinggi di mana karyawan belum mampu secara efektif serta efisien menyelesaikan pekerjaannya. Hal tersebut dapat peneliti lihat berdasarkan pengamatan di mana banyak terdapat ketidaksesuaian hasil pekerjaan dengan kualitas atau standar yang ditetapkan.

Berdasarkan hasil wawancara yang penulis lakukan oleh Bapak Rahmat salah satu QC PT Pacific Indah Pratama. Beliau mengutarakan bahwa masih tingginya kesalahan-kesalahan dalam proses pengerjaan produksi dikarenakan kekurangtahuan karyawan akan produk-produk terkini yang semakin modern. Keadaan tidak serta merta terjadi begitu saja dan diakui memang kurangnya pelatihan-pelatihan serta pengenalan akan produk-produk yang diproduksi oleh perusahaan sangat kurang diberikan kepada karyawan. Kalaupun dilakukan hanya terbilang seadanya dan akhirnya karyawan bekerja semam- 
punya saja sehingga berdampak kepada kualitas hasil kerja yang rendah dan tidak tercapainya target yang telah ditetapkan.

Pengamatan penulis lainnya penulis temukan fenomena-fenomena yang menunjukkan pelanggaran-pelanggaran waktu kerja yang dilakukan oleh sebagian karyawan. Ketepatan waktu dalam menyelesaikan pekerjaan masih terjadi di mana terdapat kelemahan dalam bekerjasama antar rekan kerja dan lebih kepada individual dalam melakukan pekerjaan. Kerjasama antar lini kerja juga masih belum terjalin dengan baik sehingga dapat menggangu ritme operasional secara keseluruhan. Kurangnya respon manajemen yang cepat dalam menyelesaikan kendala kerja karyawan menjadikan tambahan permasalahan, sehingga ketika karyawan tidak melakukan pekerjaannya dengan baik hal tersebut menjadi sesuatu yang biasa saja.

Implementasi akan tata tertib kerja karyawan PT Pacific Indah Pratama faktanya masih terdapat pelanggaran-pelanggaran yang dilakukan, sehingga kenyataannya tidak sesuai dengan harapan perusahaan. Masih rendahnya kesadaran diri karyawan pada peraturan yang ditetapkan masih sering terjadi, kondisi tersebut ditunjukkan oleh sebagian karyawan PT Pacific Indah Pratama seperti disiplin dalam hal mentaati kehadiran kerja di perusahaan. Jumlah hari ketidakhadiran karyawan di perusahaan lebih dominan pada tidak tanpa keterangan yang jelas, keadaan tersebut tentu menjadi masalah serius karena terdapat tren menurunnya kehadiran karyawan yang dapat mengganggu operasional kerja perusahaan.

Fenomena lain peneliti temukan masih seringnya karyawan memanfaatkan jam istirahat melebihi waktunya dan tidak tepat waktu ketika harus hadir kembali di tempat kerja sesuai aturan yang berlaku. Dengan keadaan di mana perilaku kurang pedulinya karyawan terhadap kedisiplinan kerja karena konsistensi dalam penegakan aturan perusahaan yang tidak baik sehingga berakibat menurunnya kinerja yang dihasilkan karyawan. Pelanggaran yang dilakukan oleh karyawan dianggap hal biasa dan kalaupun ada sangsi sebatas teguran biasa dan kurang tegas memberikan hukuman sehingga tidak menimbulkan efek jera bagi karyawan.

Perilaku kerja seseorang yang positif erat kaitannya dengan motivasi yang dimiliki, karakter, cara berpikir, sikap, etika, keyakinan, serta prinsip disiplin akan aturan-aturan kerja yang berlaku di perusahaan. Hal-hal tersebut belum mampu dengan baik ditunjukan oleh sebagian karyawan, sikap maupun perilaku karyawan yang kurang baik dapat dilihat ketika karyawan terlihat santai dan mengobrol di waktu waktu kerja. Demikian juga ketidaktepatan waktu karyawan dalam menyelesaikan tugas yang diberikan, sehingga hal tersebut menyebabkan tertundanya pekerjaan dan akan mempunyai imbas ke hal lain yang terkait dengannya.

Pengamatan penulis juga mendapati bahwa keadaan di mana karyawan PT Pacific Indah Pratama belum mampu bekerja dengan menunjukkan keterampilan serta ide-ide yang maksimal. Manajemen belum mampu memberikan kepercayaan penuh kepada karyawan untuk melaksanakan pekerjaan dan terlihat kaku sehingga aktualisasi diri karyawan untuk dapat berkontribusi kepada perusahaan tidak terlihat. Fenomena menurunnya kinerja karyawan akan mempengaruhi efektifitas serta efisiensi kerja guna mencapai visi dan misi perusahaan yang akan sulit tercapai ketika kondisi kerja tidak berjalan sebagaimana mestinya.

Dengan demikian setelah melihat permasalahan di atas, penulis dapat membuat pertanyaanpertanyaan untuk diteliti berkaitan dengan seberapa besar pengaruh variabel-variabel yang telah teridentifikasi baik secara parsial dan simultan. Lebih dalam lagi penulis tertarik untuk membuktikan kesesuaian antara teori dengan fenomena-fenomena serta fakta di lapangan dalam hal ini adalah PT Pacific Indah Pratama di mana karyawan sebagai objek penelitian.

\section{METODE}

Sesuai dengan sumber utama data penelitian yaitu kuesioner yang disebarkan kepada responden dan selanjutnya ditabulasi dalam bentuk angkaangka. Penulis menggunakan metode kuantitatif yang kemudian diolah secara statistik inferensial 
(parametris) adapun pendekatan yang digunakan berdasarkan model yang dikembangkan adalah dengan bentuk asosiatif yang bersifat kausal. Di mana keberadaan variabel prediktor $\mathrm{X}_{1}$ (etos kerja) dan $\mathrm{X}_{2}$ (disiplin kerja) dapat diteliti dan mengetahui besaran nilai pengaruhnya dengan kinerja karyawan (Y) sebagai variabel yang dipengaruhi.

\section{Populasi dan Sampel}

Cakupan objek yang diteliti adalah karyawan PT Pacific Indah Pratama, di mana total populasi sebesar 103 responden atau karyawan. Penulis dalam penelitian ini menerapkan generalisasi di mana menggunakan sampel untuk mewakili populasi, untuk menetapkan sampel penelitian maka teknik yang penulis gunakan adalah Nonprobability Sampling yaitu sampel jenuh. Dengan begitu keseluruhan populasi penulis gunakan sebagai sampel yang berjumlah 103 responden/ karyawan.

\section{Analisis Data}

Statistik yang diterapkan untuk analisis data adalah dengan menggunakan statistik inferensial yaitu parametris. Untuk itu diperlukan uji-uji prasyarat dalam model regresi yang diberlakukan dan harus terpenuhi dalam penelitian ini. Untuk proses pengujian menggunakan alat bantu olah statistik SPSS 25 for windows sedangkan tingkat presisi yang diterapkan adalah sebesar 5\% dengan uji dua arah. Adapun pengujian statistik meliputi uji validitas dan uji reliabilitas (skala likert), tansformasi data ordinal menjadi interval guna memenuhi syarat minimal bentuk data adalah interval/rasio dalam statistik parametris dengan menggunakan MSI, pengujian prasyarat asumsi dasar (normalitas data residual, multikolinieritas, dan heteroskedastisitas). Pengujian hipotesis meliputi uji Annova (uji F), pengujian parsial (uji t), analisis korelasi, analisis koefisien determinasi, serta persamaan regresi linier berganda.

\section{HASIL dan PEMBAHASAN}

Pembahasan utama penelitian berhubungan dengan variabel-variabel prediktor $\left(\mathrm{X}_{1}\right)$ yaitu etos kerja, dan $\left(\mathrm{X}_{2}\right)$ disiplin kerja, sedangkan variabel yang dipengaruhi (Y) adalah kinerja karyawan. Dasar-dasar teori dapat penulis uraikan sebagai berikut:

Sinamo dalam Donni Juni Priansa (2016: 282), mengemukakan "Etos kerja adalah seperangkat perilaku positif yang berakar pada keyakinan fundamental yang disertai komitmen total pada paradigma kerja yang integral". Sedangkan Desmon Ginting (2016:7), "Etos kerja adalah semangat kerja yang menjadi ciri khas seseorang atau sekelompok orang yang bekerja, yang berlandaskan etika dan perspektif kerja yang diyakini, dan diwujudkan melalui tekad dan perilaku konkret di dunia kerja”. Dapat penulis sintesiskan etos kerja merupakan perilaku individu dengan keselarasan semangat dan komitmen tinggi dalam berinteraksi sehingga bernilai guna untuk dirinya, orang lain, organisasi dan bangsa.

Pendapat yang dikemukakan oleh Rivai (2015:599), disiplin kerja adalah "Suatu alat yang digunakan para manajer untuk berkomunikasi dengan karyawan agar mereka bersedia untuk mengubah suatu perilaku. Serta sebagai suatu upaya untuk meningkatkan kesadaran dan kesediaan seseorang mentaati semua peraturan perusahaan dan norma-norma sosial yang berlaku". Pendapat lain dikemukakan oleh Machmed Tun Ganyang (2018:143), disiplin kerja adalah "Suatu kondisi di mana karyawan bersedia menerima, dan melaksanakan berbagai peraturan yang ada. Baik yang dinyatakan secara konkrit maupun kebiasaan yang sudah menjadi budaya, dan berhubungan dengan pelaksanaan tugas, wewenang, tanggung jawab terhadap perusahaan". Dapat penulis sintesiskan bahwa disiplin kerja bisa berfungsi sebagai alat untuk mengatur dan berkomunikasi kepada karyawan sehingga bersedia melaksanakan tugas, wewenang, sesuai norma serta aturan yang berlaku.

Mohammad Busro (2018:89), mengutarakan "Performance atau kinerja adalah hasil kerja yang dapat dicapai oleh seseorang atau kelompok orang. Dalam suatu perusahaan sesuai dengan wewenang dan tanggung jawab masing-masing dalam upaya pencapaian tujuan perusahaan yang legal, tidak melanggar hukum dan tidak 
bertentangan dengan moral dan etika". Menurut Kasmir (2018:184), "Kinerja karyawan juga diartikan sebagai suatu pelaksanaan fungsi-fungsi yang dituntut dari seseorang. Kinerja juga dikatakan sebagai suatu perbuatan, suatu prestasi, suatu unjuk keterampilan seseorang dalam mengerjakan pekerjaannya”. Dapat penulis sintesiskan bahwa kinerja karyawan merupakan suatu pencapaian kerja berdasarkan tugas serta tanggung jawab yang diemban karyawan dalam periode waktu tertentu.

\section{Hasil}

Berdasarkan sumber data utama yaitu kuesioner penelitian yang telah ditabulasi serta diberlakukan perubahan data ordinal menjadi interval, yang merupakan salah satu syarat dalam statistik parametris yang setidaknya data berbentuk inter$\mathrm{val} /$ rasio kemudian diolah dengan alat bantu statistik SPSS 25 for windows.

\section{Uji Instrumen (Validitas dan Reliabilitas)}

Sebagai salah satu syarat dalam model penelitian survei yang menggunakan data primer yaitu instrumen penelitian di mana kuesioner sebagai sumber utama perlu diuji keabsahan dan konsistensi. Adapun syarat valid jika nilai $\mathrm{r}_{\text {hitung }}$ $>\mathrm{r}_{\text {tabel }}$ sedangkan nilai $\mathrm{r}_{\text {tabel }}$ berdasarkan tabel statistik uji dua arah dengan presisi 5\% (n-2) 103$2=101$ didapat nilai 0,9137 . Untuk pengujian reliabilitas bilamana koefisien Cronbach's Alpha > 0,60 (taraf batas toleransi yang ditentukan) maka dikatakan reliabel.

\section{Uji Validitas}

Hasil uji instrumen penelitian yaitu uji validitas terangkum pada tabel 1 berdasarkan pengolahan menggunakan SPSS versi 25 dari seluruh variabel peneltian dapat tersaji sebagai berikut.

\begin{tabular}{|c|c|c|c|}
\hline \multicolumn{4}{|c|}{ Tabel 1. Rangkuman Uji Validitas } \\
\hline Etos Kerja $\left(\mathrm{X}_{1}\right)$ \\
\hline Pertanyaan & $\mathrm{r}_{\text {hitung }}$ & $\mathrm{r}_{\text {tabel }}$ & Keterangan \\
\hline QEK 1 & .484 & .1937 & Valid \\
\hline QEK 2 & .529 & .1937 & Valid \\
\hline QEK 3 & .457 & .1937 & Valid \\
\hline QEK 4 & .518 & .1937 & Valid \\
\hline
\end{tabular}

\begin{tabular}{|c|c|c|c|}
\hline QEK 5 & .572 & .1937 & Valid \\
\hline QEK 6 & .561 & .1937 & Valid \\
\hline QEK 7 & .488 & .1937 & Valid \\
\hline QEK 8 & .476 & .1937 & Valid \\
\hline QEK 9 & .565 & .1937 & Valid \\
\hline QEK 10 & .529 & .1937 & Valid \\
\hline \multicolumn{4}{|c|}{ Disiplin Kerja $\left(\mathrm{X}_{2}\right)$} \\
\hline Pertanyaan & $\mathbf{r}_{\text {hitung }}$ & $r_{\text {tabel }}$ & Keterangan \\
\hline QDK 1 & .543 & .1937 & Valid \\
\hline QDK 2 & .434 & .1937 & Valid \\
\hline QDK 3 & .548 & .1937 & Valid \\
\hline QDK 4 & .512 & .1937 & Valid \\
\hline QDK 5 & .538 & .1937 & Valid \\
\hline QDK 6 & .458 & .1937 & Valid \\
\hline QDK 7 & .537 & .1937 & Valid \\
\hline QDK 8 & .426 & .1937 & Valid \\
\hline QDK 9 & .449 & .1937 & Valid \\
\hline QDK 10 & .480 & .1937 & Valid \\
\hline \multicolumn{4}{|c|}{ Kinerja Karyawan (Y) } \\
\hline Pertanyaan & $r_{\text {hitung }}$ & $r_{\text {tabel }}$ & Keterangan \\
\hline QKK 1 & .431 & .1937 & Valid \\
\hline QKK 2 & .640 & .1937 & Valid \\
\hline QKK 3 & .602 & .1937 & Valid \\
\hline QKK 4 & .589 & .1937 & Valid \\
\hline QKK 5 & .535 & .1937 & Valid \\
\hline QKK 6 & .574 & .1937 & Valid \\
\hline QKK 7 & .635 & .1937 & Valid \\
\hline QKK 8 & .648 & .1937 & Valid \\
\hline QKK 9 & .649 & .1937 & Valid \\
\hline QKK 10 & .426 & .1937 & Valid \\
\hline
\end{tabular}

Berdasarkan tabel 1. hasil uji validitas secara keseluruhan nilai $\mathrm{r}_{\text {hitung }}$ dari setiap item-item pernyataan variabel-variabel prediktor yaitu etos kerja $\left(\mathrm{X}_{1}\right)$ maupun disiplin kerja $\left(\mathrm{X}_{2}\right)$, dan variabel yang dipengaruhi yaitu kinerja karyawan $(\mathrm{Y})$ mempunyai nilai $>\mathrm{r}_{\text {tabel }}(0,1937)$, dapat disimpulkan keseluruhan kuesioner penelitian adalah valid.

\section{Uji Reliabilitas}

Tabel 2 di bawah adalah hasil pengujian konsistensi jawaban responden berdasarkan alat bantu menggunakan SPSS yang terangkum sebagai berikut.

\begin{tabular}{|l|c|c|}
\hline \multicolumn{1}{|c|}{ Tabel 2. Rangkuman Uji Konsistensi (Reliability) } \\
\hline Variabel & Cronbach's Alpha & Kriteria \\
\hline Etos Kerja & .697 & Reliabel \\
\hline Disiplin Kerja & .649 & Reliabel \\
\hline Kinerja Karyawan & .767 & Reliabel \\
\hline
\end{tabular}


Dari rangkuman tabel 2 di atas dapat dilihat keseluruhan nilai Cronbach's Alpha di atas 0,60 yang artinya jawaban responden baik untuk variabel prediktor dan variabel yang dipengaruhi adalah reliabel.

\section{Uji Asumsi Prasyarat Model Regresi}

Uji prasyarat yang diterapkan meliputi normalitas data residual, multikolinieritas, serta heteroskedastisitas. Uji-uji tersebut dilakukan untuk terpenuhinya salah satu syarat dalam model regresi dengan bentuk statistik parametris. Hasil uji asumsi dasar dapat penulis uraikan sebagai berikut.

\section{Uji Normalitas Residual (Visual P-P Plot dan 1-KS)}

Berikut adalah output SPSS versi 25 for windows untuk uji normalitas data residual dengan pendekatan visual atau grafik P-P Plot.

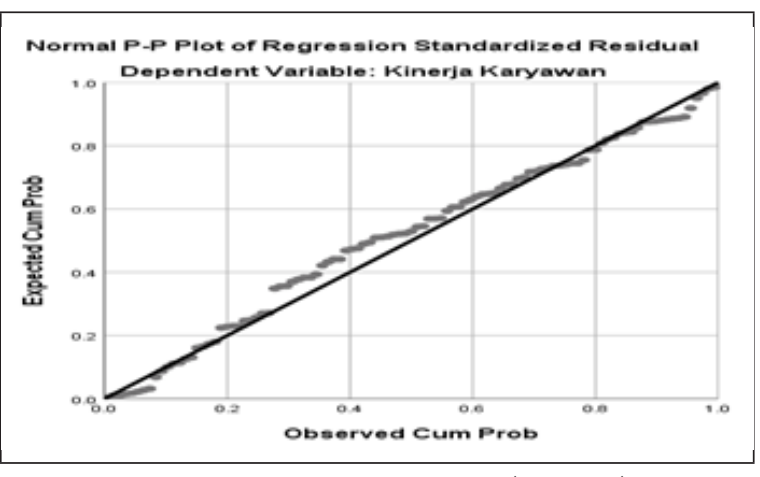

Gambar 1. Normalitas Residual (P-P Plot)

Berikut adalah output uji normalitas data residual dengan 1-Sample KS Test menggunakan SPSS versi 25 for windows.

\begin{tabular}{|l|l|r|}
\hline \multicolumn{3}{|c|}{ Tabel 3. Uji Normalitas (1-Sampel KS Test) } \\
\hline \multicolumn{2}{|c|}{ One-Sample Kolmogorov-Smirnov Test } \\
\hline $\mathrm{N}$ & & $\begin{array}{c}\text { Unstandardized } \\
\text { Residual }\end{array}$ \\
\hline Normal Parameters ${ }^{\mathrm{a}, \mathrm{b}}$ & & 103 \\
\hline Most Extreme Differences & Mean & .0000000 \\
\cline { 2 - 3 } & Std. Deviation & 3.77368161 \\
\hline & Absolute & .080 \\
\cline { 2 - 3 } & Positive & .058 \\
\cline { 2 - 3 } & Negative & .080 \\
\hline Kolmogorov-Smirnov Z & & .080 \\
\hline Asymp. Sig. (2-tailed) & & $.104^{c}$ \\
\hline $\begin{array}{l}\text { a. Test distribution is Normal. } \\
\text { b. Calculated from data. } \\
\text { c. Lilliefors Significance Correction. }\end{array}$ & \\
\hline
\end{tabular}

Hasil olah data untuk uji normalitas di atas dapat dilihat bahwa pada pendekatan visual atau grafik, distibusi data residual mengikuti dan titik-titik tidak menjauh dari digaris diagonal. Sedangkan pada pendekatan statistik menggunakan uji 1-KS dapat dilihat pada Asymp. Sig (2-tailed) 0,104 > 0,05. Kesimpulan berdasarkan pengujian dengan pendekatan grafik maupun pendekatan statistik 1-KS test adalah data residual terdistribusi normal.

\section{Uji Multikolinieritas}

Tabel 4 menjelaskan hasil pengujian multikolinieritas sebagai persyaratan lain yang harus terpenuhi. Model regresi mewajibkan tidak ada korelasi diantara variabel-variabel prediktor atau variabel bebas. Hasil uji multikolinieritas dari output SPSS versi 25 for windows dapat tersaji sebagai berikut.

\begin{tabular}{|c|c|c|c|c|c|c|c|c|}
\hline \multicolumn{9}{|c|}{ Tabel 4. Output Coefficients (Multikolinieritas) } \\
\hline \multicolumn{9}{|c|}{ Coefficients $^{\mathrm{a}}$} \\
\hline \multirow{2}{*}{\multicolumn{2}{|c|}{ Model }} & \multicolumn{2}{|c|}{$\begin{array}{l}\text { Unstandardized } \\
\text { Coefficients }\end{array}$} & \multirow{2}{*}{$\begin{array}{c}\begin{array}{c}\text { Standard- } \\
\text { ized Coef- } \\
\text { ficients }\end{array} \\
\text { Beta }\end{array}$} & \multirow{2}{*}{$t$} & \multirow{2}{*}{ Sig. } & \multicolumn{2}{|c|}{$\begin{array}{c}\text { Collinearity } \\
\text { Statistics }\end{array}$} \\
\hline & & B & $\begin{array}{l}\text { Std. } \\
\text { Error }\end{array}$ & & & & $\begin{array}{l}\text { Toler- } \\
\text { ance }\end{array}$ & VIF \\
\hline \multirow{3}{*}{1} & (Constant) & ,779 & 3,363 & &, 232 &, 817 & & \\
\hline & Etos Kerja & .428 & ,082 & .413 & 5,212 &, 000 &, 936 & 1,068 \\
\hline & Disiplin Kerja & .432 & ,086 & .396 & 4,997 &, 000 & .936 & 1,068 \\
\hline
\end{tabular}

Pada tabel output coefficients dapat dilihat collinearity tolerance didapat angka $0,936>0,1$ sedangkan VIF didapat nilai 1,068 dan $<10$. Dengan begitu dapat penulis simpulkan berdasarkan uji statistik yang dilakukan menggunakan SPSS versi 25 for windows. Pada model regresi dalam penelitian ini tidak ditemukan gejala multikolinieritas.

\section{Uji Heteroskedastisitas}

Hasil uji untuk pembuktian apakah ditemukan gejala heteroskedastisitas dapat dijelaskan pada gambar 2 di bawah yang ditampilkan dalam bentuk Scatterplot.

Salah satu asumsi dasar dalam model regresi yang harus terpenuhi adalah tidak terjadi gejala heteroskedastisitas. Pada output visual scatterplot dapat diketahui tidak adanya pola tertentu di 
mana titik-titik menyebar dengan tidak beraturan. Berdasarkan grafik tersebut dapat disimpulkan tidak terbukti adanya gejala heteroskedastisitas dalam model regresi.

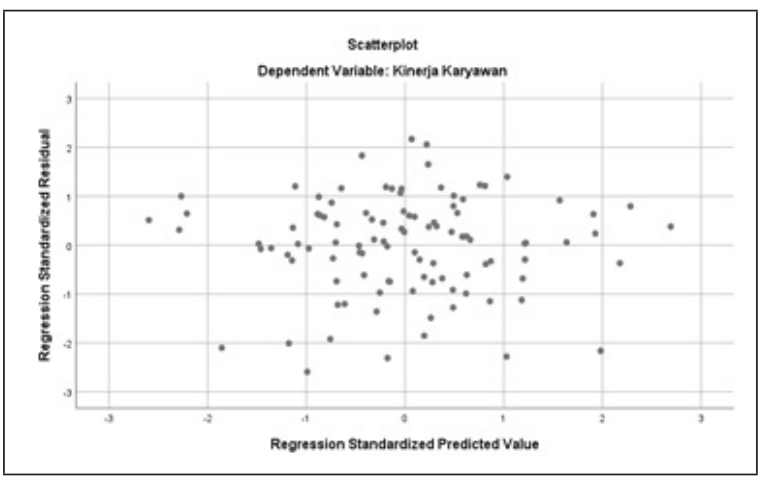

Gambar 2. Grafik Scatterplot (Heteroskedastisitas)

\section{Uji Hipotesis dan}

Persamaan Regresi Linier Berganda

Setelah prasyarat dalam model regresi terpenuhi selanjutnya dapat dilakukan pembuktian atas hipotesis penelitan yang telah dirumuskan dengan uji-uji sebagai berikut.

\section{Analisis Koefisien Korelasi Berganda}

\begin{tabular}{|c|c|c|c|c|}
\hline \multicolumn{5}{|c|}{ Tabel 5. Output Summary } \\
\hline Model & $\mathbf{R}$ & R Square & $\begin{array}{c}\text { Adjusted R } \\
\text { Square }\end{array}$ & $\begin{array}{c}\text { Std. Error of the } \\
\text { Estimate }\end{array}$ \\
\hline 1 &, $641^{\text {a }}$ &, 411 &, 399 & 3,81123 \\
\hline a. Predictors: (Constant), Disiplin Kerja, Etos Kerja \\
\hline \multicolumn{4}{|l|}{ b. Dependent Variable: Kinerja Karyawan } \\
\hline
\end{tabular}

Pada kolom kedua output summary didapat nilai koefisien korelasi (R) sebesar 0,641. Hal tersebut dapat diketahui bahwa korelasi variabelvariabel prediktor yaitu $\mathrm{X}_{1}$ (etos kerja) maupun $\mathrm{X}_{2}$ (disiplin kerja) terhadap kinerja karyawan. Mempunyai nilai korelasi sebesar 0,641 dan masuk kriteria kuat (0.600 - 0.799).

\section{Analisis Koefisien Determinasi}

Besaran kontribusi nilai persentase variabel prediktor $\mathrm{X}_{1}$ (etos kerja) serta $\mathrm{X}_{2}$ (disiplin kerja) terhadap variabel dependen $\mathrm{Y}$ (kinerja karyawan) dapat diketahui pada tabel 5 kolom Adjusted $\mathrm{R}$ Square. Berdasarkan hasil uji tersebut didapat nilai 0,399 atau jika dipersentasekan menjadi $39,9 \%$ yang merupakan besaran kontribusi etos kerja maupun disiplin kerja terhadap kinerja karyawan. Sedangkan 60,1\% merupakan variabelvariabel lain yang tidak teridentifikasi.

\section{Uji F}

Berikut adalah hasil olah data yang menggambarkan nilai pengaruh simultan variabelvariabel dependen terhadap variabel independent yang tersaji pada output anova berikut ini.

\begin{tabular}{|c|c|c|c|c|c|c|}
\hline \multicolumn{7}{|c|}{ Tabel 6. Output Anova (Uji F) } \\
\hline \multicolumn{7}{|c|}{ ANOVA $^{\mathrm{a}}$} \\
\hline \multicolumn{2}{|c|}{ Model } & $\begin{array}{l}\text { Sum of } \\
\text { Squares }\end{array}$ & Df & $\begin{array}{l}\text { Mean } \\
\text { Square }\end{array}$ & $\mathrm{F}$ & Sig. \\
\hline \multirow{3}{*}{1} & Regression & 1012,560 & 2 & 506,280 & 34,855 &, $000^{\circ}$ \\
\hline & Residual & 1452,549 & 100 & 14,525 & & \\
\hline & Total & 2465,109 & 102 & & & \\
\hline \multicolumn{7}{|c|}{ a. Dependent Variable : Kinerja Karyawan } \\
\hline \multicolumn{7}{|c|}{ b. Predictors: (Constant), Disiplin Kerja, Etos Kerja } \\
\hline
\end{tabular}

Dari output anova nilai $\mathrm{F}_{\text {hitung }}$ pada kolom kelima didapat angka 34,855 sedangkan nilai Sig pada kolom keenam adalah 0,000. Adapun nilai $\mathrm{F}_{\text {tabel }}$ berdasarkan pedoman tabel statistik pada tingkat kebenaran 95\% $(\alpha=0.05)$ didapat angka 3,09. Dengan begitu secara simultan etos kerja dan disiplin kerja berpengaruh signifikan terhadap kinerja karyawan di mana nilai 34,855 > 3,09 dan Signifikansi $(0,000<0,05)$.

\section{Uji Parsial (Uji t)}

Berikut adalah output SPSS untuk uji parsial variabel prediktor $\left(\mathrm{X}_{1}\right)$ etos kerja maupun $\left(\mathrm{X}_{2}\right)$ disiplin kerja terhadap yang dipengaruhi $(\mathrm{Y})$ kinerja karyawan.

\begin{tabular}{|c|c|c|c|c|c|c|c|c|}
\hline \multicolumn{9}{|c|}{ Tabel 7. Output Coefficients (Uji t) } \\
\hline \multicolumn{9}{|c|}{ Coefficients $^{\mathrm{a}}$} \\
\hline \multirow{2}{*}{\multicolumn{2}{|c|}{ Model }} & \multicolumn{2}{|c|}{$\begin{array}{l}\text { Unstandardized } \\
\text { Coefficients }\end{array}$} & \multirow{2}{*}{$\begin{array}{c}\begin{array}{c}\text { Standard- } \\
\text { ized Coef- } \\
\text { ficients }\end{array} \\
\text { Beta }\end{array}$} & \multirow{2}{*}{$t$} & \multirow{2}{*}{ Sig. } & \multicolumn{2}{|c|}{$\begin{array}{c}\text { Collinearity } \\
\text { Statistics }\end{array}$} \\
\hline & & B & $\begin{array}{l}\text { Std. } \\
\text { Error }\end{array}$ & & & & $\begin{array}{l}\text { Toler- } \\
\text { ance }\end{array}$ & VIF \\
\hline \multirow{3}{*}{1} & (Constant) &, 779 & 3,363 & &, 232 & .817 & & \\
\hline & Etos Kerja &, 428 & , 082 & .413 & 5,212 & 000 & , 936 & 1,068 \\
\hline & Disiplin Kerja &, 432 & , 086 & .396 & 4,997 & ,000 & .936 & 1,068 \\
\hline
\end{tabular}

Besaran koefisien variabel-variabel prediktor terhadap variabel yang dipengaruhi dapat dilihat berdasarkan nilai signifikansi pada kolom kelima dan keenam tabel 7 output Coefficients. Adapun nilai $\mathrm{t}_{\text {tabel }}$ berdasarkan panduan tabel statistik pada 
tingkat kesalahan 5\% $(0,05)$ didapat angka 1,98. Keputusan signifikansi diambil bilamana $t_{\text {hitung }}$ $>\mathrm{t}_{\text {tabel }}$ dan Sig $<0,05$ artinya terbukti signifikan. Nilai $\mathrm{t}_{\text {hitung }}$ variabel etos kerja didapat angka $(5,212$ $>1,98)$ dengan Sig $(0,000<0,05$. $)$ Sedangkan disiplin kerja didapat nilai $\mathrm{t}_{\text {hitung }}(4,997>1,98)$ dengan Sig $(0,000<0,05)$. Dapat disimpulkan variabel-variabel prediktor yaitu etos kerja maupun disiplin kerja secara parsial berpengaruh signifikan terhadap kinerja karyawan.

\section{Analisis Regresi Berganda}

Berdasarkan hasil perhitungan olah data yang tersaji pada tabel 7 output Coefficients, maka dapat dimasukan model regresi berganda dengan persamaan $\mathrm{Y}^{\prime}=\mathrm{a}+\mathrm{b}_{1} \mathrm{X}_{1}+\mathrm{b}_{2} \mathrm{X}_{2}$ sebagai berikut:

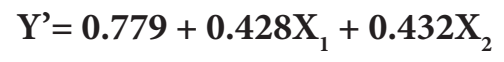

Angka-angka yang dimasukan dalam persamaan tersebut bermakna nilai 0.779 adalah konstanta (a). Jika variabel prediktor etos kerja dan variabel prediktor disiplin kerja bernilai nol atau tetap maka variabel yang dipengaruhi kinerja karyawan sudah mempunyai nilai yaitu 0,779 . Sedangkan etos kerja $\left(b_{1}\right)$ mempunyai nilai regresi 0,428 (positif) yang mengartikan jika etos kerja naik nilainya satu satuan. Kinerja karyawan meningkat senilai 0,428 dengan syarat variabel prediktor lain yaitu disiplin kerja tidak berubah atau tetap. Demikian juga koefisien regresi disiplin kerja $\left(b_{2}\right)$ sebesar 0,432 bernilai positif dapat meningkatkan kinerja karyawan sebesar satu satuan dengan syarat variabel prediktor lain yaitu etos kerja tetap.

\section{Pembahasan}

Setelah dilakukan pengujian secara statistik maka dapat penulis lakukan suatu analisis sesuai pertanyaan-pertanyaan penelitian yang diajukan dengan temuan hasil uji-uji, serta mengkaitkan dengan teori-teori yang relevan dalam pembahasan penelitian sebagai berikut:

Pertanyaan pertama yang dirumuskan adalah seberapa besar variabel prediktor yaitu etos kerja berpengaruh terhadap variabel dependen yaitu kinerja karyawan. Hasil uji instrumen kuesioner variabel etos kerja menerangkan hasil yang terbukti valid dan reliabel dengan begitu instrumen penelitian dapat mengukur sikap dan juga konsistensi jawaban responden. Berdasarkan hasil uji signifikansi terdapat nilai yang positif dan signifikan yang artinya hipotesis atau jawaban sementara diduga terdapat pengaruh etos kerja terhadap kinerja karyawan terbukti.

Jika dilihat dari distribusi jawaban responden masih didapati ketidaksetujuan karyawan bahwa karyawan dalam aktivitas pekerjaan sehari-hari selalu berusaha untuk menyelesaikan tugas dan tidak melimpahkan kepada orang lain. Demikian juga sikap kerja adalah suatu amanah belum bisa dipahami sebagian responden di mana keadaan ini dapat menjadi suatu permasalahan serius apabila tidak cepat direspon untuk diperbaiki. Secara teoritis seperti yang dikemukakan Cherrington dalam Donni Juni Priansa (2016:283), "Bahwa etos kerja mengarah kepada sikap positif pegawai terhadap pekerjaan yang diembannya". Sejalan dengan Andri Hadiansyah dalam jurnal $A l$ Azhar Indonesia Vol.3 No.2 Septermber 2015 penelitiannya mengungkapkan etos kerja terbukti positif dan juga signifikan berpengaruh terhadap kinerja karyawan.

Pertanyaan kedua penelitian adalah terkait seberapa pengaruh variabel prediktor disiplin kerja terhadap kinerja karyawan. Hasil uji instrumen variabel prediktor disiplin kerja terbukti valid dan reliabel dengan begitu untuk instrumen penelitian kedua juga dapat mengukur sikap responden dan terbukti konsisten. Berdasarkan hasil uji signifikansi variabel prediktor disiplin kerja terhadap variabel dependen kinerja karyawan menunjukkan hasil pengaruh yang positif dan terbukti signifikan. Dengan begitu hipotesis yang menyatakan diduga terdapat pengaruh disiplin kerja terhadap kinerja karyawan atau hipotesis kedua penelitian terbukti.

Selanjutnya dari hasil jawaban responden terhadap item pernyataan masih didapati ketidaksetujuan responden dalam hal karyawan selalu mematuhi aturan dalam melaksanakan tugas. Sebagian karyawan masih merasakan adanya pelanggaran-pelanggaran yang dilakukan rekanrekan kerjanya ketika melaksanakan tugasnya dan kurang mematuhi aturan perusahaan. Ketidakpatuhan karyawan terhadap aturan tentu 
akan mempunyai dampak negatif baik untuk individu itu sendiri yang dapat mempengaruhi menurunnya kinerja maupun kepada perusahaan dalam pencapaian tujuan yang ditetapkan. Sesuai yang dikemukakan oleh Tun Ganyang (2018:144), bahwa "Disiplin kerja menunjukkan kekuatan karyawan, karena pada umumnya karyawan yang memiliki kinerja baik adalah karyawan yang memiliki tingkat kedisiplinan tinggi. Guna mewujudkan tujuan perusahaan, yang pertama harus ditegakkan di perusahaan tersebut adalah kedisiplinan karyawan. Jadi, kedisiplinan merupakan kunci keberhasilan suatu perusahaan dalam mencapai tujuan". Hasil penelitian ini sejalan dengan Kenny Astria dalam jurnal Mandiri Vol. 2 No.1 Juni 2018. Di mana disiplin kerja sebagai variabel independen memiliki pengaruh positif terhadap dependennya yaitu kinerja karyawan dan terbukti signifikan.

Pertanyaan ketiga yaitu seberapa besar pengaruh etos kerja dan disiplin kerja secara simultan terhadap kinerja karyawan di mana uji instrumen variabel kinerja karyawan terbukti valid dan reliabel. Sedangkan hasil uji F didapat hasil secara simultan etos kerja dan disiplin kerja mempunyai pengaruh positif dan signifikan dengan begitu hipotesis ketiga penelitian terbukti. Berdasarkan jawaban responden dapat diketahui bahwa masih terdapat ketidakharmonisan kerja antara pimpinan dengan bawahan begitu pula dengan sesama rekan kerja di perusahaan. Pengintegrasian akan menjadi sangat penting dalam suatu aktivitas kerja sehingga akan terjalin kesepahaman diantara karyawan maupun antara manajemen dengan karyawannya.

\section{SIMPULAN}

Berdasarkan rumusan masalah yang diajukan dalam penelitian ini serta uji statistik yang telah dilakukan maka dapat dibuat kesimpulan penelitian. Untuk pertanyaan pertama didapat hasil etos kerja berpengaruh positif dan signifikan terhadap kinerja karyawan dengan hasil $(5,212>1,98)$ dengan Sig $(0,000<0,05)$. Untuk rumusan masalah kedua didapat hasil $(4,997>1,98)$ dan Sig $(0,000<0,05)$ dengan begitu pengaruh variabel disiplin kerja terhadap variabel kinerja karyawan terbukti. Sedangkan uji F didapat hasil $(34,855>3,09)$ dan Sig $(0,000<0,05)$ dengan begitu etos kerja dan disiplin kerja secara simultan terbukti berpengaruh positif serta signifikan terhadap kinerja karyawan.

\section{PENGHARGAAN}

Terima kasih dan apresiasi penulis ucapkan kepada PT Pacific Indah Pratama, yang telah mendukung terlaksananya penelitian ini hingga selesai. Penulis berharap semoga penelitian ini dapat menjadi pertimbangan dan berguna untuk kemajuan PT Pacific Indah Pratama.

\section{DAFTAR PUSTAKA}

Badriyah, M. (2019). Manajemen Sumber Daya Manusia. Bandung: CV Pustaka Setia.

Busro, M. (2018). Teori-Teori Manajemen Sumber

Daya Manusia. Jakarta: Prenadamedia Group.

Fahmi, I. (2017). Manajemen Sumber Daya Manusia Teori dan Aplikasi. Bandung: CV Alfabeta.

Ganyang, M. T. (2018). Manajemen Sumber Daya Manusia Konsep dan Realita. Bogor: Penerbit IN MEDIA.

Ginting, D. (2016). Etos Kerja: Panduan Menjadi Karyawan Cerdas. Jakarta: PT Elex Media Komputindo.

Handoko, T. H. (2014). Manajemen Personalia Dan Sumberdaya Manusia. Yogyakarta: BPFE-Yogyakarta.

Hasibuan, M. S. (2016). Manajemen: Dasar, Pengertian, dan Masalah. Jakarta: PT Bumi Aksara.

Kasmir. (2018). Manajemen Sumber Daya Manusia (Teori dan Praktik). Depok: PT Rajagrafindo Persada.

Marwansyah. (2016). Manajemen Sumber Daya Manusia. Bandung: CV Alfabeta.

Priansa, D. J. (2016). Perencanaan dan Pengembangan Sumber Daya Manusia. Bandung: CV Alfabeta.

Riduwan, \& Engkos, A. K. (2017). Cara Mudah Menggunakan dan Memaknai Path Analysis 
(Analisis Jalur). Bandung: Alfabeta.

Sedarmayanti. (2019). MANAJEMEN SUMBER

DAYA MANUSIA Reformasi Birokrasi dan

Manajemen Pegawai Negeri Sipil. Bandung:

PT Refika Aditama.

Sekaran, U., \& Bougie, R. (2017). Metode Penelitian untuk Bisnis. Jakarta: Salemba Empat.

Sinambela, L. P. (2018). Manajemen Sumber Daya Manusia. Jakarta: PT Bumi Aksara.

Sugiyono. (2017). Statistika untuk Penelitian.
Bandung: CV Alfabeta.

Suparyadi. (2015). Manajemen Sumber Daya Manusia - Menciptakan Keunggulan Bersaing Berbasis Kompetensi SDM. Yogyakarta: CV Andi Offset.

Sutrisno, E. (2019). Manajemen Sumber Daya Manusia. Jakarta: Prenadamedia Group.

Zainal, V. R., \& dkk. (2015). Manajemen Sumber Daya Manusia untuk Perusahaan: Dari Teori ke Praktik. Jakarta: Rajawali Pers. 